Pécsi Tudományegyetem, Klinikai Központ, Fogászati és Szájsebészeti Klinika, Pécs*

Szegedi Tudományegyetem, Fogorvostudományi Kar, Fogpótlástani Tanszék, Szeged ${ }^{\star *}$

Pécsi Tudományegyetem, Általános Orvostudományi Kar, Bioanalitikai Intézet, Pécs ${ }^{\star \star \star}$

Pécsi Tudományegyetem, Általános Orvostudományi Kar, Magatartástudományi Intézet, Pécs ${ }^{\star * * *}$

\title{
A depresszió és a szorongás, valamint a temporomandibularis diszfunkció feltételezett összefüggésének vizsgálata
}

\author{
DR. SOMOSKÖVI ISTVÁN*, DR. RADNAI MÁRTA**, DR. DERGEZ TÍMEA***, \\ DR. RADÁCSI ANDREA*, DR. TIRINGER ISTVÁN ${ }^{\star \star \star *}$, DR. NAGY ÁKOS KÁROLY*
}

\begin{abstract}
Az egyetemi hallgatókat tanulmányaik során különböző pszichés stresszhatások érik, ezek vizsgaidőszakban fokozódhatnak, és hatásukra egyeseknél szorongásos és depressziós tünetek jelentkezhetnek. A temporomandibularis diszfunkció kialakulásában a beteg pszichés állapota mint etiológiai tényező gyakran kerül említésre a szakirodalomban, de az összefüggés jellege nem pontosan tisztázott. Kutatásunkban azt vizsgáltuk, hogy a vizsgaidőszakban megjelennek-e szorongásos vagy depressziós tünetek, illetve változik-e a fogorvostan-hallgatók tüneteinek mértéke, valamint a temporomandibularis diszfunkció tüneteinek és egyes orális parafunkcióknak a gyakorisága, és összefüggést kerestünk az egyes tényezők között. Kérdőíves adatgyűjtést végeztünk két időpontban: egyszer a szorgalmi-, és egyszer a vizsgaidőszakban. A kérdőíveket a Diagnostic Criteria for Temporomandibular Disorders (DC/TMD) magyar változatából vettük. Összehasonlítottuk a temporomandibularis diszfunkció tüneteinek gyakoriságát, a szorongás és a depreszszió mértékét, valamint az arcfájdalom intenzitásának különbségét a két időpontban. Eredményeink az mutatták, hogy a hallgatók szorongásos és depressziós tünetei szignifikánsan magasabb szintet értek el vizsgaidőszakban, mint szorgalmi időszakban. A temporomandibularis diszfunkció valamennyi vizsgált tünete szintén nagyobb gyakorisággal fordult elő vizsgaidőszakban. Ekkor a tünetek közül a fájdalom több mint kétszer annyi hallgatónál volt jelen, mint szorgalmi időszakban. A fájdalom intenzitása is szignifikánsan magasabb volt vizsgaidőszakban. A vizsgált orális parafunkciók mértékében is jelentős emelkedést találtunk. Eredményeink alapján feltételezhető, hogy vizsgaidőszakban a hallgatók fokozott stressz-szintje növeli a szorongásos és depressziós tünetek mértékét és ez egybeesik a temporomandibularis tüneteik nagyobb arányú és mértékű előfordulásával. A kettő közötti kapcsolat nem bizonyítható, de elképzelhető, hogy az emelkedett stressz-szint is hozzájárul a temporomandibularis diszfunkció tüneteinek megjelenéséhez vagy fokozódásához.
\end{abstract}

Kulcsszavak: bruxizmus, depresszió, pszichés stressz, szorongás, temporomandibularis diszfunkció

\section{Bevezetés}

Az állkapocsízületek és az azokat körülvevő struktúrák (elsősorban a rágóizomzat) funkcionális elváltozásait temporomandibularis diszfunkciónak/rendellenességnek (TMD), illetve más nomenklatúra szerint craniomandibularis diszfunkciónak (CMD) nevezzük. A betegség tünetei közül karakterisztikus a temporomandibularis ízületben, rágóizmokban, illetve a fül előtti területen jelentkező fájdalom, az állkapocsmozgások rendellenessé válása, a különféle ízületi hangjelenségek, és egyéb, úgynevezett melléktünetek (például arcfájdalom, fejfájás, fülzúgás) [13].

A TMD prevalenciája magas, egy közelmúltban végzett felmérés a teljes populációban 5-12\% közé teszi a gyakoriságát [12]. Ezzel a második leggyakoribb muszkulo-szkeletális elváltozás a krónikus hátfájdalmat követően és a leggyakoribb, nem fog eredetú fájdalomforrás az orofaciális régióban.

Bár számos ellentmondás és vita jellemzi ezen betegségcsoport diagnosztikáját és terápiáját, abban többékevésbé egyetértés mutatkozik, hogy a TMD etiológiáját tekintve multifaktoriális elváltozás. A számos lehetséges kóroki tényező alapvetően három fő csoportba sorolható: biomechanikai, neuromuszkuláris és pszichoszociális [18].

Az elmúlt évtizedekben több kutatás vizsgálta a TMD és a beteg pszichológiai státuszának kapcsolatát. Krónikus állkapocsízületi, illetve orofaciális fájdalomban szenvedők esetében szignifikánsan magasabb pszichés stressz-szintet és fájdalom-katasztrofizálást (felnagyítást) sikerült kimutatni [3,8]. Az is megállapításra került, hogy az emelkedett pszichés stressz és depresszió kockázati tényezőként szerepelhet a krónikus TMD-fájdalom kialakulása szempontjából [10]. 
A felsőoktatási intézmények oktatói folyamatosan tapasztalják a hallgatóik körében magas arányban mutatkozó fokozott stressz és szorongás jeleit. Ezek a tapasztalatok azonban nyilvánvalóan szubjektívek, reálisabb megközelítést azok a vizsgálatok tesznek lehetővé, amelyek valamilyen objektív módszerrel vizsgálták a felsőoktatásban tanulók pszichoszociális érintettségét.

Világszerte több vizsgálat is arra az eredményre jutott, hogy egyetemi hallgatók körében a populációs átlaggal összehasonlítva magasabb gyakorisággal fordulnak elő pszichés problémák. Fawzy és mtsai. egyiptomi orvostanhallgatók között igen magas arányban találtak depressziót (65\%), szorongást $(71 \%)$ és emelkedett stressz-szintet (60\%) [4]. Egy 2010-ben az Egyesült Királyságban végzett felmérés is rámutat arra, hogy az egyetemi hallgatók a tanulmányaik során változó, a korábbi életükhöz képest emelkedett mértékű szorongással és depressziós tünetekkel küzdenek [2]. Silverstein megállapítása szerint az USA-ban a fogorvostan-hallgatók stressz-szintje az első tanévben lényegesen meghaladta a beiratkozás előtti állapotot [14]. StewartBrown és mtsai. arról számoltak be, hogy a felsőoktatásban résztvevők több mint harmadában a szorongás olyan mértékü volt, hogy az jelentősen akadályozta őket a tanulásban [17]. Hazánkban is vizsgálták az orvostanhallgatókat érő stresszt és annak hatásait. A Szegedi Tudományegyetemen egy 2012-ben végzett kutatás összefüggést talált a hallgatók stressz-terheltsége, pszichoszomatikus tünetképzése, a különböző coping formák és az élettel való elégedettségük között [11]. Egy másik hazai tanulmány is rámutat a pszichés zavarok magas előfordulási arányára az orvostanhallgatók körében, és rámutat a korai felismerés és a megfelelő segítség igénybevételének fontosságára a kiégés elkerülése érdekében [6].

A rendelkezésre álló adatokból és az egyetemi környezetben szerzett tapasztalatainkból egyaránt megállapítható, hogy az egyetemi hallgatóknak a tanulmányaikkal és a gyakran új élethelyzettel összefüggő kihívásokból eredően fokozott stressz-helyzetekkel, és esetleg az ezekből fakadó szorongásos-depressziós tünetekkel is szembesülniük kell. A vizsgaidőszakokban ezek a helyzetek sorozatosan ismétlődnek, így feltételezhető a következményes tünetek erősödése is. Mindez lehetőséget ad az ilyen jellegú (környezeti) stressz hatásainak vizsgálatára.

Jelen kutatásunk célja az volt, hogy a felsőoktatásban részt vevő hallgatók körében felmérjük a stressz következtében fellépő szorongás és depressziós tünetek mértékét, valamint a TMD fő tüneteinek (fájdalom, ízületi hangjelenségek, állkapocsmozgás-korlátozottság) gyakoriságát. Vizsgáltuk, hogy a hallgatók pszichés állapotának változása és a TMD tüneteinek incidenciája között mutatkozik-e kapcsolat. Hipotézisünk az volt, hogy a vizsgaidőszak során a hallgatókat érő fokozott stressz magasabb szorongási szintet és súlyosabb depresszív állapotot eredményez, és ez ismert (például az orális parafunkciók fokozódása által) vagy nem ismert mó- don, egyes esetekben hatással lehet a TMD tüneteinek előfordulására és/vagy mértékére.

Kíváncsiak voltunk arra is, hogy a fájdalom intenzitásában volt-e különbség a két időpontban, továbbá, hogy a fájdalom mértékét befolyásolta-e a szorongás és a depressziós állapot. Végül megvizsgáltuk az orális parafunkciók gyakoriságának különbségét szorgalmi és vizsgaidőszakban.

\section{Vizsgálati anyag és módszer}

A kutatás módszere kérdőíves adatgyưjtés volt, klinikai vizsgálat nem történt. A kutatásban résztvevők a Pécsi Tudományegyetem Általános Orvostudományi Kar, Fogorvosi Szak negyed és ötödéves, magyar anyanyelvü hallgatói közül kerültek ki, önkéntes alapon. A hallgatók a betegtájékoztató elolvasása után, a beleegyező nyilatkozat aláírásával járultak hozzá a vizsgálatban való részvételhez. A résztvevők adatait a hatályos adatvédelmi szabályok betartásával gyújtöttük és dolgoztuk fel.

A hallgatók két időpontban töltötték ki a kérdőíveket: szorgalmi időszakban (T1) és vizsgaidőszakban (T2). A T1 időpontot a szorgalmi időszak középső harmadában, a T2 időpontot pedig a vizsgaidőszak második felében határoztuk meg, mivel a hallgatók által kitöltött kérdőívek kérdései jelentős részben a megelőző 30 napra vonatkoztak.

A kutatásból kizártuk azokat, akik hiányosan töltötték ki a kérdőíveket, továbbá azokat, akik a két időpont között a TMD-vel kapcsolatban kezelésben részesültek. A végleges minta így 59 fő volt (17 férfi, 42 nő).

A résztvevők a Diagnostic Criteria for Temporomandibular Disorders (DC/TMD) magyar nyelvű változatának kérdőíveit töltötték ki. A DC/TMD egy nemzetközi kutatócsoport által, a TMD és arcfájdalmak diagnosztikájára kifejlesztett, angol nyelvű eszköz, amelyet 2014ben publikáltak [12]. A korábbi diagnosztikus rendszerekhez képest pontosan meghatározott kritériumok szerint vezet a diagnózishoz. Mivel a DC/TMD egységesen, reprodukálható módon működik, megfelel a bizonyítékon alapuló orvoslás feltételeinek. Az eredetileg angol nyelvű DC/TMD-t az elmúlt években több nyelvre lefordították és számos országban használják elsősorban kutatási célokra. A magyar nyelvre történő fordítását 2017-ben fejezte be kutatócsoportunk [15].

A DC/TMD a klinikai betegvizsgálat és a páciens által kitöltendő kérdőívek segítségével gyújt adatokat. Egyik fő jellemzője, hogy két tengely mentén alkot diagnózist. Az első tengely a TMD fizikális diagnózisát szolgáltatja (például discus dyslocatio reductióval, vagy kisugárzó myofascialis fájdalom), a második tengely pedig a beteg pszichoszociális állapotával és a TMD-vel kapcsolatos életminőség-változásával kapcsolatban ad információt. Az első tengely diagnózisaihoz a klinikai vizsgálat és a Tüneti Kérdőív eredményei alapján jutunk. Jelen kutatásban klinikai vizsgálat nem történt, a hallgatók a kérdőív kitöltésével adtak információt TMD tüneteik esetleges jelenlétéről. 
A Tüneti Kérdőív kutatásunkban figyelembe vett pontjai a TMD fő tüneteire kérdeznek rá: az állkapocsban, halántékon, fülben, vagy a fül előtti területen érzett fájdalomra, halántéktáji fejfájásra, állkapocsízületi hangokra, valamint zárt, illetve nyitott helyzetben történő akadásra, méghozzá a megelőző 30 napra vonatkozóan.

A második tengely diagnózisokhoz használt számos kérdőív közül a PHQ-9 (Patient Health Questionnaire - 9, magyar neve: Kérdőív az Ön egészségi állapotáról - 9 kérdéses változata) a beteg depressziós állapotát (1. ábra), a GAD-7 (Generalized Anxiety Disorder Assessment-7 kérdéses változata) pedig a szorongás mértékét képes mérni (2. ábra) [7, 16]. A PHQ-9 és a GAD-7 értékelése egy 0-3-ig terjedő skálán jelölt válaszok pontozásával és az összpontszám kalkulálásával történt. A PHQ-9 és a GAD-7 kérdőívek nemzetközileg elfogadott és alkalmazott eszközök a depresszió és a szorongás diagnosztikájában.

A szintén a második tengelyhez tartozó Krónikus Fájdalom Értékelése kérdőív a fájdalom mint a TMD általában vezető tünetének mértékét képes mérni. A kutatásunkban felhasznált kérdések (3. ábra) a jelenlegi, illetve az elmúlt 30 napban tapasztalt legerősebb és átlagos fájdalom intenzitást (CPI: Chronic Pain Intensity) mérik egy 0-10-ig terjedő skálán.

A Kérdőív a szájüregi funkciók felmérésére kérdéssora az alvás közben, illetve éber állapotban észlelt orális parafunkciók és rossz szokások gyakoriságát méri. Ebből azokat a pontokat emeltük ki (4. ábra), melyek a bruxizmusra vonatkozóan szolgáltatnak információt, mivel a bruxizmus általánosan elfogadott etiológiai tényező a TMD-ben.

Mindenekelőtt felmértük a szorongás és a depreszszió mértékét a megkérdezett hallgatók körében szorgalmi és vizsgaidőszakban. Megvizsgáltuk továbbá, hogy a TMD fő tüneteinek milyen volt az előfordulási gyakorisága a két időpontban, és hogy mutatkozik-e nemek közötti eltérés a tünetek gyakoriságában.

Az adatok statisztikai analízise IBM SPSS Statistics 25 szoftver segítségével történt. A szorongás és depressziós pontszámok két időpontban történő összevetésére kétmintás t-próbát használtunk. A TMD tünetek előfordulási gyakoriságának összehasonlítására kereszttábla elemzést és chi-négyzet próbát végeztünk. A fájdalomintenzitás pontszámok összevetésére páros t-próbát és Wilcoxon-próbát alkalmaztunk, míg a szorongás és depresszió kapcsolatát a fájdalomintenzitással Spearman-féle rangkorrelációval vizsgáltuk. A parafunkciók gyakoriságát a két időpontban Wilcoxon-próbával hasonlítottuk össze. A statisztikai elemzéseknél a különbségeket $p<0,05$ értéknél tekintettük szignifikánsnak.

\section{Eredmények}

A szorongás (GAD-7) pontszám átlagos értéke 5,31 $(\mathrm{SE}=0,61)$ volt szorgalmi időszakban (T1) és 9,71
$(\mathrm{SE}=0,75)$ vizsgaidőszakban (T2). Ez szignifikáns különbséget jelent $(p=0,000)$ (5. ábra).

A depresszió (PHQ-9) pontszám átlaga 5,27 (SE = $0,55)$ volt szorgalmi $(T 1)$ és $8,27(\mathrm{SE}=0,68)$ vizsgaidőszakban (T2). Ez szintén szignifikáns eltérést jelent ( $p=0,001)$ (5. ábra).

A TMD egyes tüneteinek előfordulási gyakoriságát a 6. ábra mutatja be. A temporomandibularis fájdalom (Tüneti Kérdőív 3. kérdés) szorgalmi időszakban az 59 hallgatóból 15-nél (25,4\%), vizsgaidőszakban viszont már 31-nél (52,5\%) volt jelen. Ez igen jelentős különbséget mutat a TMD vezető tünetében $(p=0,003)$.

A halántéktáji fejfájás esetében (Tüneti Kérdőív 5. kérdése) szintén nagyobb előfordulást mértünk vizsgaidőszakban (25 fő, 42,4\%), mint szorgalmi időszakban (20 fő, 33,9\%), de a különbség itt statisztikailag nem volt szignifikáns ( $p=0,343)$.

Az állkapocsízületi hangok tekintetében (Tüneti Kérdőív 8. kérdése) szintén nem adódott szignifikáns különbség ( $p=0,216)$. Ugyanakkor itt is elmondható, hogy a tünet a százalékos eloszlásokat tekintve nagyobb gyakorisággal fordult elő vizsgaidőszakban (T1: 17 fő, 28,8\%, T2: 23 fő, 39,7\%).

A nyitott vagy zárt helyzetben történő ízületi akadásokat vizsgálva is hasonló eredményeket kaptunk, tehát nagyobb előfordulást a T2 időpontban, ami azonban statisztikailag nem szignifikáns eltérés $(p=0,331$ a zárt és $p=0,059$ a nyitott akadás esetében). Itt meg kell jegyezni, hogy a pozitív választ adók száma alacsony volt: vizsgaidőszakban is mindössze 4-4 fő jelezte a száj zárásakor vagy nyitása közben akadás jelenlétét.

Megvizsgáltuk az egyes tünetek gyakoriságát nemi megoszlás tekintetében is. Valamennyi vizsgált tünet magasabb arányban fordult elő nőkben és az állkapocsízületi hangok esetében ez a különbség statisztikailag is szignifikáns volt (nőknél 41,7\%, férfiaknál 15,2\%, p =0,007).

A fájdalom intenzitása (CPI) a szorgalmi időszakban 7,29, vizsgaidőszakban 11,98, ami szignifikáns emelkedést jelent $(p=0,014)$.

A szorongás, illetve depresszió mértéke és az arcfájdalom intenzitása között nem találtunk szignifikáns kapcsolatot (CPI - GAD-7 [ $p=0,347$ ], illetve CPI - PHQ-9 [p = 0,250]).

Az orális parafunkciók (Kérdőív a szájüregi funkciók felmérésére) gyakoriságának eltérése a vizsgaidőszak és a szorgalmi időszak tekintetében három esetben volt egyértelműen, statisztikailag szignifikáns: az ébrenléti fogszorítás $(p=0,019)$, ébrenléti fogcsikorgatás $(p=0,013)$ és az izmok feszítése, szorítása $(p=0,001)$ (7. ábra).

\section{Megbeszélés}

Kutatásunk részeként klinikai vizsgálat nem történt, a TMD tüneteit a DC/TMD Tüneti Kérdőív adatai, tehát a hallgatók beszámolója alapján azonosítottuk. Célunk ugyanis nem az volt, hogy a hallgatókat pontos fizikális 
1. ábra: PHQ-9 (Patient Health Questionnaire - 9)

\section{Kérdőív az Ön egészségi állapotáról - 9}

Az elmúlt 2 hétben milyen gyakran okoztak Önnek gondot az alábbi panaszok?

$(\checkmark$ vagy $\times$ jellel jelölje a válaszát!)

Egyszer Néhány
sem napok $\begin{gathered}\text { najdnem } \\ \text { több, minden } \\ \text { mint } \\ \text { felében }\end{gathered}$

1. Kevés érdeklődés vagy örömérzés tevékenységei során

$\begin{array}{llll}0 & 1 & 2 & 3\end{array}$

2. Szomorúság, lehangoltság vagy reménytelenség

3. Nehezen tud elaludni, éjszaka könnyen felébred, vagy túl sokat alszik

4. Fáradtság vagy kevés energia

5. Rossz étvágy vagy túlzott evés

6. Rossz érzések saját magával kapcsolatban, vagy olyan gondolatok, hogy Ön sikertelen,
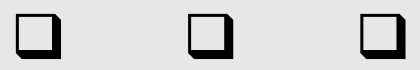
vagy csalódást okozott önmaga vagy családja számára

7. Koncentrálási nehézségek például újságolvasás vagy tévénézés közben

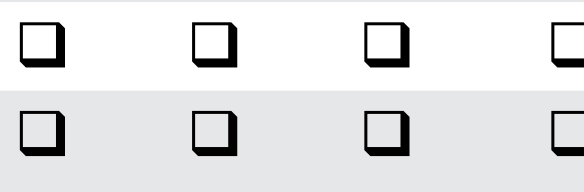

. Mozgása vagy beszéde annyira lelassult, hogy mások is észrevehették, $\square \quad \square$ vagy ellenkezőleg, olyan nyugtalan volt, hogy a szokásosnál sokkal többet mozgott

9. Olyan gondolatok, hogy jobb lenne meghalni, vagy hogy valamilyen módon
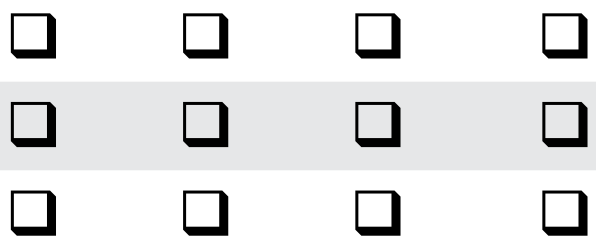
kárt tehetne önmagában

TELJES PONTSZÁM (Orvos tölti ki.) =

Amennyiben bejelölt egy vagy több problémát, mekkora nehézséget okoztak ezek a problémák a munkahelyén, otthoni teendői ellátásában vagy más emberekkel való kapcsolatában?

\begin{tabular}{|c|c|c|c|}
\hline $\begin{array}{c}\text { Egyáltalán nem okoztak } \\
\text { nehézséget }\end{array}$ & $\begin{array}{c}\text { Kis nehézséget } \\
\text { okoztak }\end{array}$ & $\begin{array}{c}\text { Nagy nehézséget } \\
\text { okoztak }\end{array}$ & $\begin{array}{c}\text { Kifejezetten } \\
\text { nagy nehézséget okoztak }\end{array}$ \\
$\square$ & $\square$ & $\square$ & $\square$ \\
\hline
\end{tabular}

A kérdőívet Dr Robert L. Spitzer, Janet B.W.Williams, Kurt Kroenke és munkatársaik állították össze a Pfizer Inc. által nyúitott oktatási ösztöndíj igénybevétele mellett.

- Engedély nélkül másolható, lefordítható, megjeleníthető és terjeszthető.

Translation modified by Somoskovi I, Radnai M at University of Pécs. 
2. ábra: GAD-7 (Generalized Anxiety Disorder Assessment - 7)

\section{GAD-7}

Az elmúlt 2 hétben milyen gyakran zavarták az alábbi problémák?

$(\checkmark$ vagy $\times$ jellel jelölje a válaszát!)

Egyszer Néhány A napok Majdnem
sem napig több, minden
mint nap
felében

$\begin{array}{llll}0 & 1 & 2 & 3\end{array}$

1. Idegesnek, szorongónak vagy feszültnek érezte magát

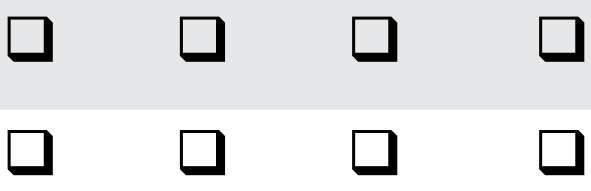
illetve uralni az aggodalmaskodást

3. Túl sokat aggódott különböző dolgok miatt

4. Nehezen tudott ellazulni

5. Olyan nyugtalan volt, hogy nehezen tudott egy helyben ülni

6. Könnyen bosszússá vagy ingerültté vált

7. Félt attól, hogy valami szörnyűség történhet

TELJES PONTSZÁM (Orvos tölti ki.) =

Amennyiben bejelölt egy vagy több problémát, mekkora nehézséget okoztak ezek a problémák a munkahelyén, otthoni teendői ellátásában vagy más emberekkel való kapcsolatában?

\begin{tabular}{c|c|c|c|}
\hline $\begin{array}{c}\text { Egyáltalán nem okoztak } \\
\text { nehézséget }\end{array}$ & $\begin{array}{c}\text { Kis nehézséget } \\
\text { okoztak }\end{array}$ & $\begin{array}{c}\text { Nagy nehézséget } \\
\text { okoztak }\end{array}$ & $\begin{array}{c}\text { Kifejezetten } \\
\text { nagy nehézséget okoztak }\end{array}$ \\
$\square$ & $\square$ & $\square$ & $\square$ \\
\hline
\end{tabular}

Copyright Pfizer Inc. No permission required to reproduce, translate, display, or distribute.

Source instrument available at http://www.phqscreeners.com/

Consortium version 12May2013. Available at http://www.rdc-tmdinternational.org/

diagnózissal besoroljuk a TMD valamelyik alcsoportjába, hanem az, hogy panaszaik meglétéről vagy hiányáról információt szerezzünk.

Az egyetemi vizsgaidőszakok komoly próbatétel elé állítják a hallgatókat és a vizsgák sikeres teljesítése nemcsak a tananyag elsajátításának, hanem az egyén pszichés állapotának is függvénye. A vizsga-szituációk és az azokat megelőző „várakozási” időszak nyilvánvalóan a pszichés stressz-szint emelkedésével járnak. Ennek mértéke és megjelenési formája egyénenként eltérő, azonban az ismétlődő és akár hónapokig fennál- ló stresszhelyzetek nyomot hagyhatnak a hallgatókban. Van Praag biokémiai szinten igazolta, hogy a stressz bizonyos depressziós jegyek, szorongás és agresszió kialakulásához vezethet [19]. Könnyen elképzelhető tehát az is, hogy egyes hallgatókban éppen az egyetemi tanulmányaikkal összefüggésben „elszenvedett” stressz vezet a szorongás vagy depresszió megjelenéséhez.

A kutatásunkban nemzetközileg elfogadott kérdőíveket használtunk a depresszió és szorongás felmérésére (PHQ-9 és GAD-7). Eredményeink szerint a vizsgált 
3. ábra: Krónikus Fájdalom Értékelése kérdőív kivonata

\section{Krónikus Fájdalom Értékelése \\ (2. verzió - 1 hónap)}

- Hogyan értékelné az arcfájdalmát JELENLEG? Jelölje a fájdalmat a 0-10-ig terjedő skálán, ahol 0 jelentése „nincs fájdalom”, a 10 pedig a „létező legnagyobb fájdalom”!

\begin{tabular}{|c|c|c|c|c|c|c|c|c|c|c|}
\hline \multicolumn{2}{|c|}{$\begin{array}{l}\text { Nincs } \\
\text { fájdalom }\end{array}$} & & & & & & & & \multicolumn{2}{|c|}{$\begin{array}{l}\text { Létező legnagyobb } \\
\text { fájdalom }\end{array}$} \\
\hline \begin{tabular}{l|l|} 
& 0
\end{tabular} & 1 & 2 & 3 & 4 & 5 & 6 & 7 & 8 & 9 & 10 \\
\hline
\end{tabular}

- Hogyan értékelné az ELMÚLT 30 NAPBAN előforduló LEGNAGYOBB arcfájdalmát? Jelölje ismét a 0-10-ig terjedő skálán, ahol 0 jelentése „nincs fájdalom”, a 10 pedig a „létező legnagyobb fájdalom”!

\begin{tabular}{|c|c|c|c|c|c|c|c|c|c|c|}
\hline \multicolumn{2}{|c|}{$\begin{array}{l}\text { Nincs } \\
\text { fájdalom }\end{array}$} & & & & & & & & \multicolumn{2}{|c|}{$\begin{array}{l}\text { Létező legnagyobb } \\
\text { fájdalom }\end{array}$} \\
\hline \begin{tabular}{l|l} 
& 0
\end{tabular} & 1 & 2 & 3 & 4 & 5 & 6 & 7 & 8 & 9 & 10 \\
\hline
\end{tabular}

- Az ELMÚLT 30 NAPBAN ÁTLAGOSAN milyennek értékelné az arcfájdalmát?

Jelölje ismét a 0-10-ig terjedő skálán, ahol 0 jelentése „nincs fájdalom”, a 10 pedig a „létező legnagyobb fájdalom”! [Ez a szokásos mértékú fájdalom, amikor fájt.]

\begin{tabular}{|c|c|c|c|c|c|c|c|c|c|c|c|}
\hline \multicolumn{2}{|c|}{$\begin{array}{l}\text { Nincs } \\
\text { fájdalom }\end{array}$} & & & & & & & & \multicolumn{3}{|c|}{$\begin{array}{l}\text { Létező legnagyobb } \\
\text { fájdalom }\end{array}$} \\
\hline \begin{tabular}{l|l|} 
& 0
\end{tabular} & 1 & 2 & 3 & 4 & 5 & 6 & 7 & 8 & 9 & 10 & \\
\hline
\end{tabular}

hallgatók szorongás és depressziós tüneteinek mértéke jelentősen magasabb volt a vizsgaidőszakban és több esetben súlyosnak tekinthető szintet ért el. Ez a korábbi tanulmányok eredményeivel összhangban rámutat a prevenció és a korai kezelés fontosságára.

Az általunk vizsgált hallgatók TMD tüneteinek incidenciája is egyértelműen magasabb volt vizsgaidőszakban. Különösen a temporomandibularis területen jelentkező fájdalmat tekintve tapasztaltunk jelentős különbséget, ami a szorgalmi időszakhoz képest megkétszereződött és a hallgatók több mint felében jelen volt. Ráadásul az érintett hallgatókban a fájdalom intenzitása is lényegesen nagyobb volt vizsgaidőszakban. Az állkapocsízületben és rágóizomzatban jelentkező fájdalom a TMD egyik fő (és egyben leggyakoribb) tünete. Akár akutan jelentkező fájdalomról van szó, akár egy krónikus betegség fellángolásaként jelentkezőről, annak negatív hatása van az egyén életminőségére.

A többi vizsgált tünet (temporális fejfájás, ízületi hangok, ízületi akadás) gyakorisága is magasabb volt vizsgaidőszakban, de ezeknél a különbség nem volt szignifikáns. Valamennyi tünet gyakrabban fordult elő nőkben, ami megfelel a szakirodalomban szereplő adatoknak.
A szájüregi parafunkciók közül a bruxizmus egyes elemeinek (fogcsikorgatás, fogszorítás, izmok feszítése, szorítása) előfordulását vizsgáltuk, mivel a szakirodalom ezeket gyakran a pszichés stressz testi manifesztációjának tekinti [1]. Amennyiben ezt a tételt elfogadjuk, nem meglepő, hogy a hallgatók körében jelentősen magasabb volt a bruxizmus megjelenése vizsgaidőszakban. Vizsgálatunk szerint a nappali (ébrenléti) parafunkciók gyakorisága nagyobb mértékben növekedett, mint az éjszakaiaké. Elképzelhető, hogy a hallgatókat nap közben érő stressz (például egy vizsgaszituáció) a nappali bruxizmust fokozottan indukálja. Ugyanakkor nem szabad figyelmen kívül hagyni, hogy az éjszakai parafunkciókra vonatkozó kérdésekre kapott válaszok megbízhatósága mindig sokkal rosszabb, mint az ébrenlétiekre vonatkozóké.

Eredményeink szerint a megkérdezett fogorvostanhallgatók körében igen magas arányban jelentkeztek a TMD egyes tünetei a vizsgaidőszak során és ezzel párhuzamosan mind a szorongás és depresszió, mind a bruxizmus mértéke növekedett. Több kutatás is bizonyította, hogy korábban meglévő pszichoszociális tényezők növelik új, krónikus fájdalommal járó betegségek (pl. krónikus derékfájdalom) kialakulásának esé- 
4. ábra: Kérdőív a szájüregi funkciók felmérésére kivonata

\section{Kérdőív a szájüregi funkciók felmérésére}

Az elmúlt hónap alapján, Ön milyen gyakran végzi az alábbi tevékenységeket?

Ha egy tevékenység gyakorisága változó, akkor válassza a nagyobb értéket!

$(\checkmark$ vagy $\times$ jellel jelölje a válaszát minden egyes pontnál és egy pontot se hagyjon ki!)

\begin{tabular}{lcl}
\hline $\begin{array}{l}\text { Alvás közben elöforduló } \\
\text { tevékenységek }\end{array}$ & $\begin{array}{c}\text { Soha Kevesebb, 1-3 éjjel } 1-3 \text { éjjel } \\
\text { mint } 1 \text { éjjel havonta héjjel } \\
\text { havonta }\end{array}$ \\
\hline
\end{tabular}

1. Fogainak összeszorítása vagy csikorgatása alvás közben (akkor is, ha ezt más mondta Önnek)

2. Olyan helyzetben alszik, amiben az állkapcsát nyomás éri (például a hasán vagy az oldalán)

\begin{tabular}{llll}
\hline $\begin{array}{l}\text { Éber állapotban előforduló } \\
\text { tevékenységek }\end{array}$ & Soha & Ritkán & Időnként Gyakran Mindig \\
\hline
\end{tabular}

3. Fogainak csikorgatása, amikor ébren van

4. Fogainak összeszorítása, amikor ébren van

5. Fogainak összenyomása, összeérintése vagy zárt helyzetben tartása

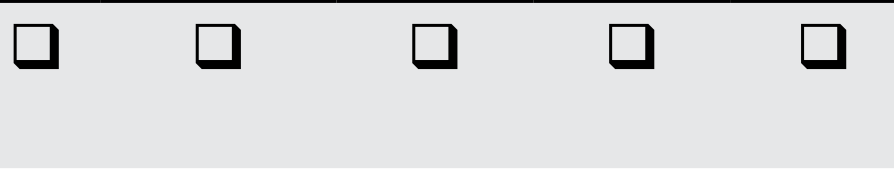
étkezésen kívül (azaz amikor az alsó és felső fogai érintkeznek)

6. Izmainak szorítása, megfeszítése, illetve feszes helyzetben tartása anélkül, hogy fogait összeérintené vagy összeszorítaná

lyét [9]. Fillingim és mtsai. egy nagy esetszámú, kohort vizsgálat elemzése által egyértelmüen igazolták egyes pszichoszociális faktorok fokozott jelenlétét TMD-ben szenvedő betegekben [5]. Mindazonáltal a koincidencia önmagában nem bizonyítja, hogy a vizsgált tényezők (szorongás, depresszió - bruxizmus - TMD tünetek) előfordulása és mértéke között összefüggés van, továbbá az esetleges összefüggés irányát sem. Elképzelhető ugyanis, hogy a TMD különböző formáiban szenvedőkben éppen a betegségük tünetei (krónikus fájdalom, funkciók beszúkülése, betegségtudat) okoznak emelkedett stressz-szintet és ennek következtében fokozódó szorongást és esetenként depresszió kialakulását.

A hallgatókat két időpontban kérdeztük meg: egyszer a szorgalmi- és egyszer vizsgaidőszakban. Ez a két időpont nyilván csak a hallgató pillanatnyi állapotáról ad információt és nem fedi le a köztes időszakot, amiben az egyént számos olyan hatás éri, ami mind a pszichés, mind a testi állapotát befolyásolja. Ráadásul a vizsgaidőszak az élet több területén is változással jár (pl. étkezési és alvási szokások, hosszú tanulással töltött időszakok során tartós ülőpozíció stb.) és ezek is 
5. ábra: A szorongás (GAD-7) és depresszió (PHQ-9) pontszámok átlagértéke szorgalmi (T1) és vizsgaidőszakban (T2)

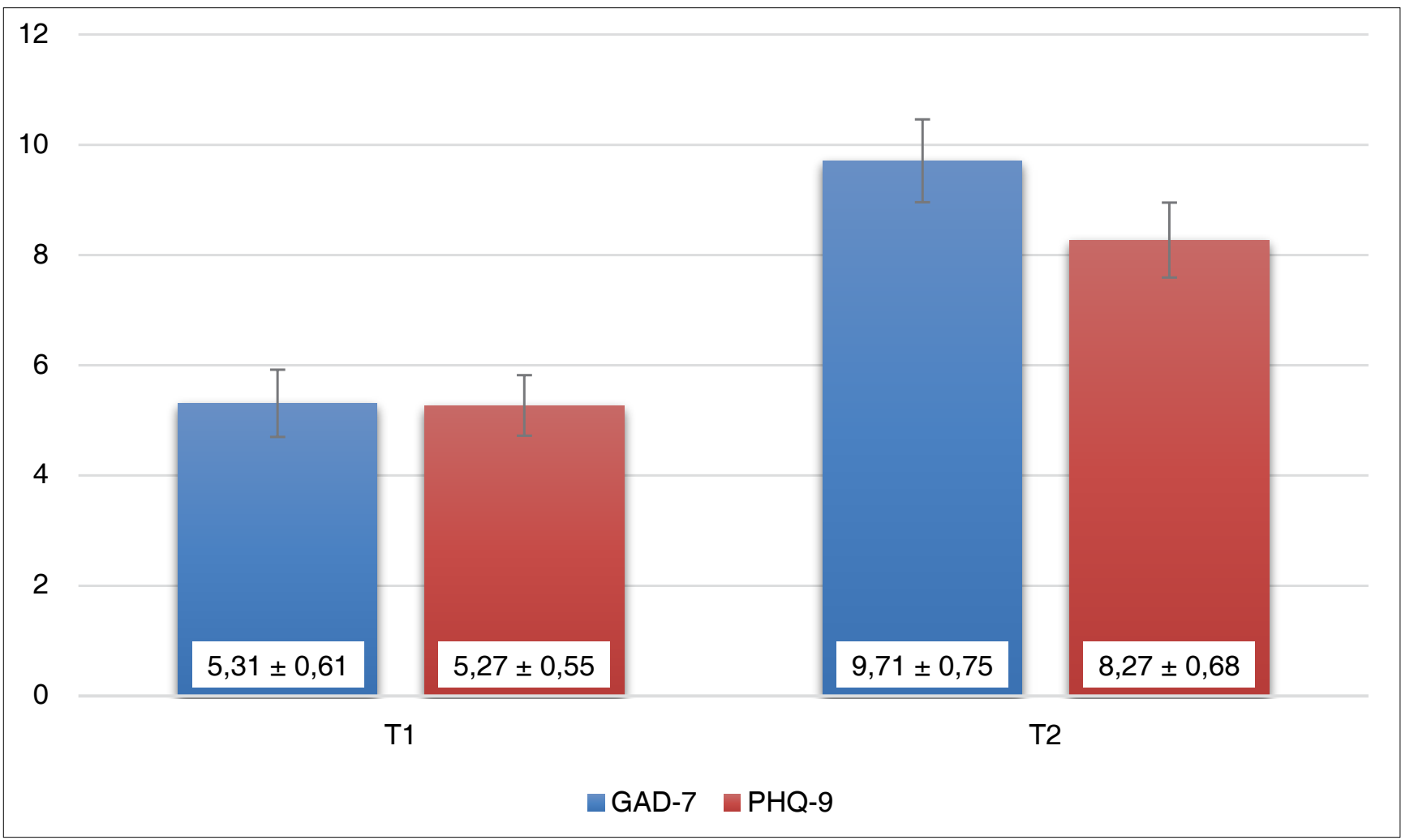

6. ábra: A TMD egyes tüneteinek előfordulása szorgalmi (T1) és vizsgaidőszakban (T2)

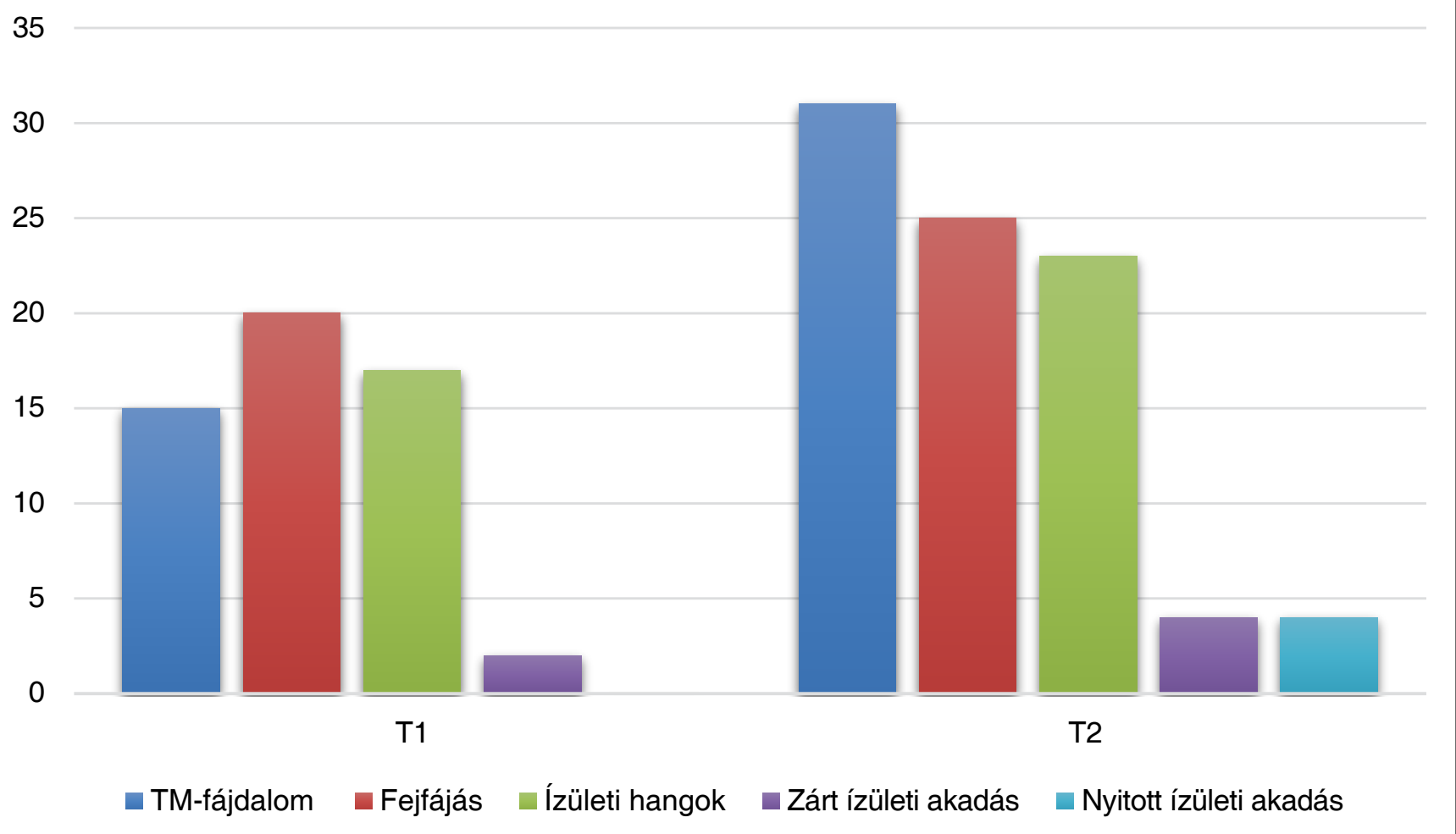


7. ábra: A vizsgált orális parafunkciók előfordulásának gyakorisága közötti különbség szorgalmi (T1) és vizsgaidőszakban (T2)

\begin{tabular}{|l|c|}
\hline $\begin{array}{l}\text { ORÁLIS PARAFUNKCIÓK } \\
\text { (Bruxizmus) }\end{array}$ & $\begin{array}{c}\text { KÜLÖNBSÉG T1 ÉS T2 IDŐPONT KÖZÖTT } \\
\text { (Wilcoxon teszt) }\end{array}$ \\
\hline $\begin{array}{l}\text { Fogainak összeszorítása vagy csikorgatása } \\
\text { alvás közben }\end{array}$ & $\mathrm{p}=0,182$ \\
\hline Fogainak csikorgatása, amikor ébren van & $\mathrm{p}=0,013^{*}$ \\
\hline Fogainak összeszorítása, amikor ébren van & $\mathrm{p}=0,019^{*}$ \\
\hline $\begin{array}{l}\text { Fogainak összenyomása, összeérintése vagy } \\
\text { zárt helyzetben tartása étkezésen kívül (azaz } \\
\text { amikor az alsó és felső fogai érintkeznek) }\end{array}$ & $\mathrm{p}=0,107$ \\
\hline $\begin{array}{l}\text { Izmainak szorítása, megfeszítése, illetve } \\
\text { feszes helyzetben tartása anélkül, hogy fogait } \\
\text { összeérintené vagy összeszorítaná }\end{array}$ & $\mathrm{p}=0,001^{*}$ \\
\hline
\end{tabular}

hatással lehetnek a pszichés állapotra és attól függetlenül a TMD tüneteire is. Ezen tényezők mindegyikét nem tudtuk felmérni kutatásunkban. Azonban a kapott eredményeinkre, legalábbis tendencia szinten mint további kutatások lehetséges kiindulópontjára tekinthetünk.

A TMD egy multifaktoriális etiológiájú kórkép, ráadásul az egyes tényezők időben sem mutatnak azonos

\section{Irodalom}

1. Ahlberg J, Lobbezoo F, Ahlberg K, Manfredini D, Hublin C, Sinisalo J et al: Self-reported bruxism mirrors anxiety and stress in adults. Med Oral Patol Oral Cir Bucal. 2013; 18: e7-11. https://doi.org/ 10.4317/medoral.18232

2. Bewick B, Koutsopoulou G, Miles J, Slaa E, Barkham M, et al: Changes in undergraduate students' psychological well-being as they progress through university. Stud High Educ. 2010; 35: 633645. https://doi.org/10.1080/03075070903216643

3. Campbell CM, Kronfli T, Buenaver LF, Smith MT, Berna C, HayTHORNTHWAITE JA, et al: Situational versus dispositional measurement of catastrophizing: associations with pain responses in multiple samples. J Pain. 2010; 11: 443-453. https://doi.org/10.1016/ j.jpain.2009.08.009

4. FawzY M, Hamed SA: Prevalence of psychological stress, depression and anxiety among medical students in Egypt. Psychiat Res. 2017; 255: 186-194. https://doi.org/10.1016/j.psychres.2017.05.027

5. Fillingim RB, Ohrbach R, Greenspan JD, Knott C, Dubner R, Bair E, et al: Psychological Factors Associated With Development of TMD: The OPPERA Prospective Cohort Study. J Pain. 2013; 14: T75-90. https://doi.org/10.1016/j.jpain.2013.06.009

6. HAZAG A, MAJOR J: A hallgatói kiégés jelensége, medikusok lelki egészségvédelme. Mentálhigiéné és Pszichoszomatika. 2008; 4: 305-322. https://doi.org/10.1556/Mental.9.2008.4.2

7. Kroenke K, Spitzer RL, Williams JB: The PHQ-9: validity of a brief depression severity measure. J Gen Intern Med. 2001; 16: 606613. https://doi.org/10.1046/j.1525-1497.2001.016009606.x

8. Leeuw R, Bertoli E, Schmidt JE, Carlson CR, et al: Prevalence of traumatic stressors in patients with temporomandibular disorders. J Oral Maxillofac Surg. 2005; 63: 42-50. https://doi.org/10.1016/ j.joms.2004.04.027

9. LINTON SJ: Do psychological factors increase the risk for back pain in the general population in both a cross-sectional and prospective analysis? Eu J Pain. 2005; 9: 355-361. https://doi.org/10.1016/ j.ejpain.2004.08.002 karakterisztikát. Akut hatások (pl. trauma) ugyanúgy iniciálhatják a betegséget, mint évek óta fennállók (pl. rendellenes fej- és testtartás). Ezért a számos lehetséges etiológiai faktor azonosítása és a köztük fennálló esetleges összefüggések megállapítása rendkívül nehéz feladat. A jövő kutatásainak fontos feladata lesz ezen összefüggések keresése és tisztázása.

10. Ohrbach R, Dworkin SF: Five-year outcomes in TMD: relationship of changes in pain to changes in physical and psychological variables. Pain. 1998; 74: 315-326. https://doi.org/10.1016/S0304 -3959(97)00194-2

11. PIкó B: Stressz, coping és a pszichikai jóllét összefüggései preklinikai orvostanhallgatók körében. Orv Hetil. 2014; 33: 1312-1318. https://doi.org/10.1556/OH.2014.29953

12. Schiffman E, Ohrbach R, Truelove E, Look J, Anderson G, GouLET JP, et al: Diagnostic Criteria for Temporomandibular Disorders (DC/TMD) for clinical and research applications: recommendations of the International RDC/TMD Consortium Network and Orofacial Pain Special Interest Group. J Oral Fac Pain Headache. 2014; 28: 6-27. https://doi.org/10.11607/jop.1151

13. Schmidt $P$ : A craniomandibularis diszfunkció epidemiológiája és etiológiája. In: Hermann P, Szentpétery A. (szerk.): Gnatológia. Semmelweis Kiadó, Budapest, 2018; 258.

14. Silverstein ST, Kritz-Silverstein D: A longitudinal study of stress in first-year dental students. J Dent Educ. 2010; 74: 836-848.

15. SomoskövI I, Radácsi A, Nagy Á, RadnaI M: A Diagnostic Criteria for Temporomandibular Disorders (DC/TMD) magyar nyelvű változatának létrehozása. Fogorv Szle. 2018; 2: 44-51.

16. Spitzer RL, Kroenke K, Williams JB, Löwe B: A brief measure for assessing generalized anxiety disorder: the GAD-7. Arch Intern Med. 2006; 166: 1092-1097. https://doi.org/10.1001/archinte.166 .10 .1092

17. Stemart-Brown S, Evans J, Patterson J, Petersen S, Doll h, BALDING J, et al: The health of students in institutes of higher education: an important and neglected public health problem? J Public Health Med. 2000; 22: 492-499. https://doi.org/10.1093/pubmed/22.4.492

18. Testa M, Geri T, Pitance L, Lentz P, Gizzi L, Erlenwein J, et al: Alterations in jaw clenching force control in people with myogenic temporomandibular disorders. J Electromyogr Kines. 2018; 43: 111-117. https://doi.org/10.1016/j.jelekin.2018.07.007

19. Van PraAg HM: Can stress cause depression? Prog Neuropsychopharmacol Biol Psychiatry. 2004; 28: 891-907. https://doi.org/ 10.1016/j.pnpbp.2004.05.031 
Somoskövi I, Radnai M, Dergez T, Radácsı A, Tiringer I, Nagy ÁK

Evaluation of the suspected relationship between anxiety, depression and temporomandibular disfunction

Introduction: University students are exposed to psychological stress, which can be increased in exam period and, as a result, symptoms of anxiety and depression may develop in some. According to previous studies, psychological status as an etiologic factor may play a role in the development of temporomandibular disorders. However, the nature of this correlation has not been clearly demonstrated. Our aim was to investigate how the levels of anxiety and depression, incidence of symptoms of temporomandibular disorders and certain oral parafunctions change in exam period. We searched for possible relationship between these factors.

Materials and method: Questionnaire-based data collection was performed among dental undergraduate students at set times in the semester, and in the exam period, using the Hungarian version of the Diagnostic Criteria for Temporomandibular Disorders (DC/TMD). Incidence of temporomandibular symptoms, level of anxiety and depression, presence of oral parafunctions and intensity of pain were compared over the two periods.

Results: Anxiety and depression scores were significantly higher in the exam period than in the semester. All measured symptoms of temporomandibular disorders were more frequent and incidence of pain has doubled (from $25,4 \%$ to $52,5 \%)$. Pain intensity and levels of oral parafunctions were also significantly higher in the exam period. Among parafunctions, daytime bruxism showed the most prevalent increase.

Discussion: Our results suggest that higher stress levels in exam periods increase the degree of anxiety and depression, which coincides with higher frequency and severity of symptoms of temporomandibular disorders. Although correlation between these two phenomena is difficult to prove, it is possible that higher stress-levels may contribute to the onset or aggravation of temporomandibular disorders. Bruxism is supposed to be a physical manifestation of psychological stress and therefore, it may play a role as a link between psychological conditions and temporomandibular symptoms.

Keywords: anxiety, bruxism, depression, psychological stress, temporomandibular disorders

\section{Javaslat a fogászati betegellátás fokozatos újraindításának feltételeiről}

A Magyar Fogorvosok Egyesülete egy nyolcfős szakértői team segítségével és széleskörű nemzetközi irodalom felhasználásával elkészítette a fogászati tevékenységek újrakezdésének feltételrendszerét tartalmazó javaslatot, amely nem írja felül az EMMI által kiadott, hivatalos eljárásrendet, de annak lényegi alapját képezte.

\section{Bevezető}

A COVID-19 járvány gyors terjedése más óvintézkedések mellett a fogorvosi ellátórendszer aktivitásának sürgősségi ellátásra történő korlátozását is indokolttá tette.

A védekezés második szakaszába lépve szükségszerúvé vált a meghatározott körülmények szigorú betartása mellett mind a közfinanszírozott, mind pedig a magán fogorvosi ellátórendszerben felhalmozódott fogászati beavatkozások fokozatos újraindításának megszervezése. Ennek elmaradása vagy késleltetése a fogazati állapot jelentősebb romlásával járhat, illetve az általános egészségre is negatív hatással lehet. Javasolt a jövőben is az előzetes időpontfoglalás gyakorlatának folytatása, mellyel elkerülhetővé válik az ellátórendszer hirtelen túlterhelése miatti későbbi keresztfertőződések kialakulása.

Az újrainduló ellátás fokozott óvintézkedéseinek kidolgozásánál figyelembe kell venni, hogy a járványért felelős SARS-CoV-2 vírus elleni oltóanyag rövid távon nem lesz elérhetó, illetve egy biztonságos és hatásos oltóanyag rendelkezésre állása esetén is időt igényel a tömeges alkalmazása.

A fogászati alap- és szakellátás alapvetően egy jól szabályozott infekciókontroll alapokon nyugvó egészségügyi ágazat. Ennek megfelelően fokozatos újraindítása a már meglévő szabályzók alapján, célzott módosításokkal végrehajtható folyamat. 